\title{
Evaluation of methane generation rate and potential from selected landfills in Malaysia
}

\author{
M. F. M. Abushammala • N. E. A. Basri • \\ A. A. H. Kadhum - H. Basri - A. H. El-Shafie • \\ S. A. Sharifah Mastura
}

Received: 5 February 2012/Revised: 28 May 2012/ Accepted: 28 January 2013/Published online: 22 February 2013

(C) Islamic Azad University (IAU) 2013

\begin{abstract}
Methane emissions and oxidation were measured during the wet and dry seasons at the Air Hitam, Jeram, and Sungai Sedu landfills in Malaysia. The resulting levels of methane emissions and oxidation were then modeled using the Inter-governmental Panel on Climate Change 1996 first order decay (FOD) model to obtain methane generation rate and potential values. Emissions measurements were performed using a fabricated static flux chamber. A combination of gas concentrations in soil profiles and surface methane and carbon dioxide emissions at four monitoring locations in each landfill was used to estimate the methane oxidation capacity. The methane potential value was $151.7 \mathrm{~m}^{3} \mathrm{t}^{-1}$ for the Air Hitam and Jeram sanitary landfills and $75.9 \mathrm{~m}^{3} \mathrm{t}^{-1}$ for the Sungai Sedu open dumping landfill. The methane generation rate value of the Jeram and Air Hitam sanitary landfills during the wet season was 0.136 year $^{-1}$, while that of Jeram during the dry season was 0.072 year $^{-1}$. The methane generation rate values of the Sungai Sedu open dumping
\end{abstract}

M. F. M. Abushammala $(\bowtie) \cdot$ N. E. A. Basri · H. Basri .

A. H. El-Shafie

Department of Civil and Structural Engineering,

Faculty of Engineering and Built Environment,

Universiti Kebangsaan Malaysia, 43600 Bangi,

Selangor, Malaysia

e-mail: eng_abushammala@yahoo.com

\section{A. A. H. Kadhum}

Department of Chemical and Process Engineering,

Faculty of Engineering and Built Environment,

Universiti Kebangsaan Malaysia, 43600 Bangi,

Selangor, Malaysia

S. A. Sharifah Mastura

Institute of Climate Change, Universiti Kebangsaan Malaysia,

43600 Bangi, Selangor, Malaysia landfill during the wet and dry seasons were 0.008 and 0.0049 year $^{-1}$, respectively. The observed values of methane generation rate and potential assist to accurately estimate total methane emissions from Malaysian landfills using the Inter-governmental Panel on Climate Change FOD model.

Keywords Flux chamber - Methane emission - Methane oxidation · Open dumping

\section{Introduction}

Accurate estimation of methane $\left(\mathrm{CH}_{4}\right)$ emission from Malaysian landfills is crucial for the development of clean development mechanism (CDM) projects. Estimating $\mathrm{CH}_{4}$ emissions from landfills entails large uncertainties due to the lack of data on waste management and emissions. In the past, $\mathrm{CH}_{4}$ emissions from landfills have usually been estimated using statistics on population and waste quality and quantity (IPCC 1996). However, many models for estimating $\mathrm{CH}_{4}$ emissions are currently available (Scharff and Jacobs 2006). The Inter-governmental Panel on Climate Change (IPCC) introduced three tiers for estimating total national $\mathrm{CH}_{4}$ emissions from landfills: Tier 1, Tier 2, and Tier 3. The Tier 1 method, defined as the default method, is based on a mass balance approach to estimate total national emissions and uses a number of empirical constant parameters, e.g., a methane correction factor (MCF), degradable organic carbon (DOC) and dissimilated organic fraction converted into landfill gas (LFG) $\left(\mathrm{DOC}_{\mathrm{f}}\right)$ (Kumar et al. 2004). The Tier 2 and Tier 3 methods are based on a first order decay (FOD) model to calculate the level of emissions (IPCC 2006). Selection of the most appropriate method to determine $\mathrm{CH}_{4}$ emissions is based 
on the availability of current and historical country-specific data on waste deposited in landfills.

The FOD model is one of the most important and widely used models for the estimation of $\mathrm{CH}_{4}$ emissions from landfills. It has been formalized as an IPCC Waste Model by the IPCC $(1996,2006)$ and a Landfill Gas Emission Model (LandGEM) by the US Environmental Protection Agency (USEPA 1998, 2005). As such, both the IPCC and USEPA recommend this model as a standard tool for the estimation of $\mathrm{CH}_{4}$ emissions from landfills. The FOD model provides a time-dependent emission profile reflecting the pattern of waste degradation over time. It assumes that the DOC in waste decays slowly over time during which $\mathrm{CH}_{4}$ and $\mathrm{CO}_{2}$ are formed. Thus, the $\mathrm{CH}_{4}$ emissions from deposited waste are highest during the first few years after deposition and then gradually decline with the reduction of DOC content in the waste (IPCC 2006). The IPCC has provided two FOD models for estimating $\mathrm{CH}_{4}$ emissions from landfill sites, the first was developed using the revised IPCC (1996) guidelines and the second is provided in the 2006 IPCC guidelines. These two FOD models are referred to herein as the IPCC 1996 FOD and IPCC 2006 FOD models, respectively. The IPCC 1996 FOD model requires data on the average annual waste acceptance rate during a landfill's active life, the $\mathrm{CH}_{4}$ generation rate $(k)$, and the $\mathrm{CH}_{4}$ generation potential $\left(L_{\mathrm{o}}\right)$ (IPCC 1996). The IPCC 2006 FOD model provides a spreadsheet interface to facilitate its implementation for national emission estimations. In contrast with the IPCC 1996 FOD model, the IPCC 2006 FOD model is easier to apply and is more precise in cases where country-specific key parameters and high-quality country-specific activity data on waste landfilling are available. Due to the absence of historical waste composition data for Malaysian landfills, implementation of the IPCC 2006 FOD model results in inaccurate emission estimation. However, application of the IPCC 1996 FOD model requires knowledge of $k$ and $L_{\mathrm{o}}$ values. This assertion is supported by Abushammala et al. (2011), who reported the limitations of both the IPCC 1996 FOD and the IPCC 2006 FOD models in estimation of total $\mathrm{CH}_{4}$ emission from landfills in Malaysia. These limitations were the lack of historical waste composition data and the assumptions made for $k$ and $L_{\mathrm{o}}$ values. IPCC (1996) reported that $L_{\mathrm{o}}$ values range from less than 100 to over $200 \mathrm{~m}^{3} \mathrm{t}^{-1}$ based on buried waste compositions, while $k$ values may range from less than 0.005-0.4 year $^{-1}$. Accordingly, the main aim of this study is to improve estimation of $\mathrm{CH}_{4}$ emissions from Malaysian landfills using the IPCC 1996 FOD model by generalizing values for $k$ and $L_{\mathrm{o}} \cdot \mathrm{CH}_{4}$ emissions and oxidation were measured at three landfills (two sanitary landfills and one open dumping landfill) during the wet (September-December 2010) and dry (January-July 2011) seasons in Malaysia, and the results were modeled with the IPCC 1996 FOD model to obtain $k$ and $L_{\mathrm{o}}$ values.

\section{Materials and methods}

Landfill selection

Malaysia is a tropical country and classified as a developing nation, situated in the heart of Southeast Asia with a total land area of $329,847 \mathrm{~km}^{2}$. It is divided into West Malaysia (Peninsular Malaysia), which comprises 11 states and one Federal Territory (Kuala Lumpur-capital of Malaysia); and East Malaysia (Borneo), which comprises Sabah, Sarawak states, and Labuan Federal Territory. Landfills are the mainly practiced for waste disposal in Malaysia. According to data obtained from the Ministry of Housing and Local Government, a total of 288 landfills were situated in Malaysia in 2004; $57 \%$ of these are still in operation and the rest have been closed. Selangor state and Kuala Lumpur Federal Territory comprised 26 landfills; 4 are sanitary landfills, 16 are open dumping landfills, and 6 are of an unknown type. To measure $\mathrm{CH}_{4}$ emissions and oxidation, landfills were selected from the Selangor state based on the landfill operational type (sanitary landfill or open dumping), landfill status (in operation or closed), location in Selangor, the availability of an inactive area at operational landfills, and ease and safety of landfill access. Thus, three landfills were selected: the Air Hitam sanitary landfill, the Jeram sanitary landfill, and the Sungai Sedu open dumping landfill (Fig. 1).

Air Hitam sanitary landfill is located in the south west of the Kuala Lumpur city at a distance of about $18 \mathrm{~km}$ from the city center, exactly lies between $3^{\circ} 00^{\prime} 05^{\prime \prime} \mathrm{N}$ and $101^{\circ} 39^{\prime} 37^{\prime \prime} \mathrm{E}$. The landfill was received approximately 400 tons per day. It started receiving waste in December 1995 and closed in 31 December 2006. It contains of seven phases filled with domestic waste. The landfill area is 42 ha.

The Jeram sanitary landfill is located in Mukim Jeram, $20 \mathrm{~km}$ North west of Kuala Lumpur, exactly lies between $3^{\circ} 11^{\prime} 20^{\prime \prime} \mathrm{N}$ and $101^{\circ} 21^{\prime} 50^{\prime \prime} \mathrm{E}$. The landfill total area is 52 ha including six phases for waste disposal, and was designed to receive approximately 2,050 tons of waste per day within 10-year lifespan operation started from 2007.

The Sungai Sedu open dumping landfill is located in Kuala Langat, in the southwestern part of Selangor, exactly lies between $2^{\circ} 50^{\prime} 39^{\prime \prime} \mathrm{N}$ and $101^{\circ} 31^{\prime} 01^{\prime \prime} \mathrm{E}$. The landfill has a total area of 5.5 ha including six cells for waste disposal. The landfill was received approximately 340 tons of domestic and non-hazardous industrial waste per day. Currently, the landfill is full and, as a result, was closed in 2010. Table 1 provides a summary of the specifications of the selected landfills. 
Fig. 1 Location of study landfills

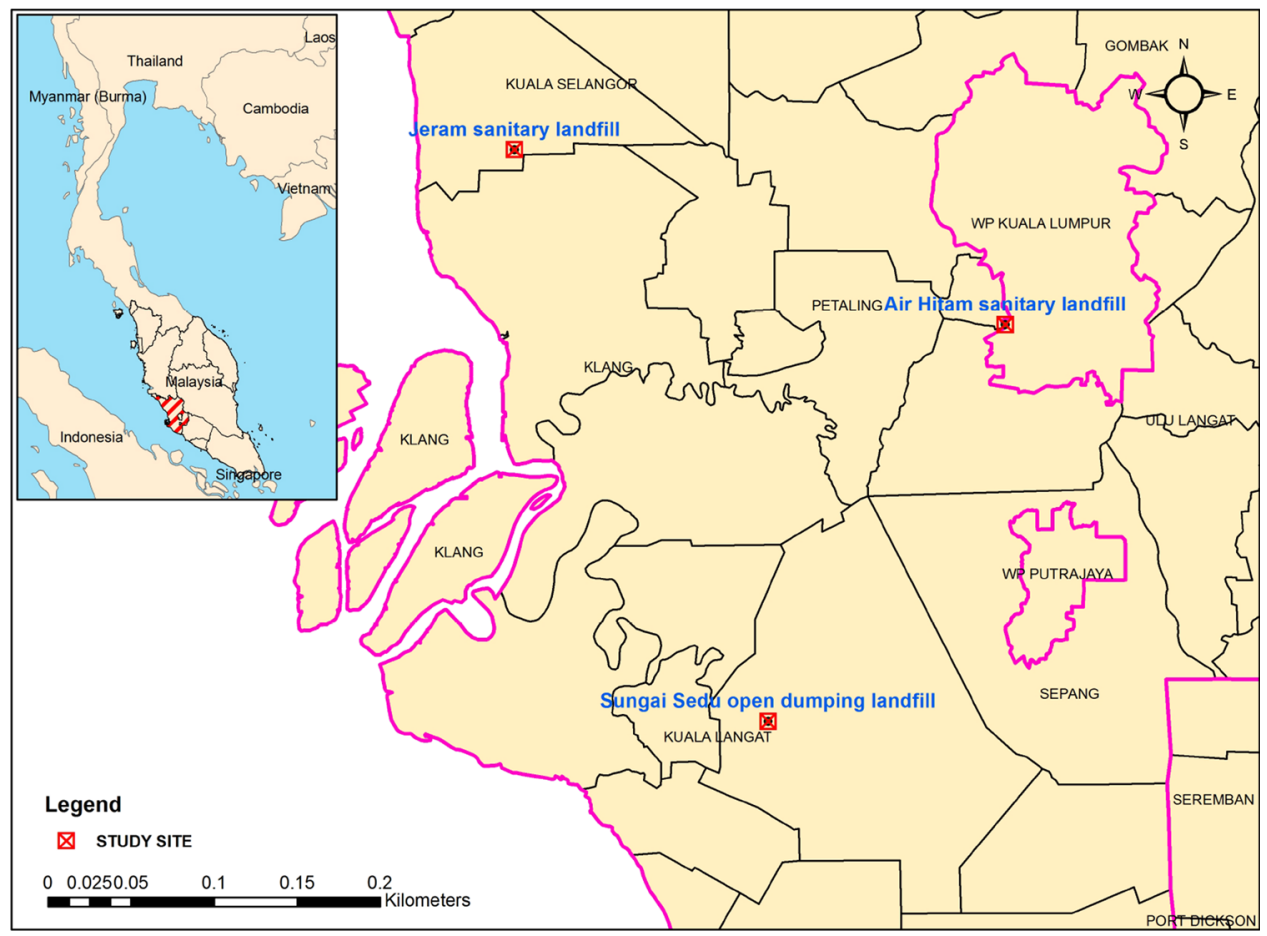

Table 1 Summary of landfill specifications

\begin{tabular}{llll}
\hline Characteristic & Air Hitam & Jeram & Sungai Sedu \\
\hline Disposal practice & Sanitary & Sanitary & Open dump \\
Status & Closed & In operation & Closed \\
$\begin{array}{l}\text { Area (ha) } \\
\text { Year operation }\end{array}$ & 42 & 52 & 5.5 \\
$\quad 1995$ & 2007 & 1996 \\
began & & & 2010 \\
Closure year & 2006 & 2017 & September \\
$\begin{array}{l}\text { Date of study } \\
\text { October }\end{array}$ & September & 2010 \\
$\begin{array}{l}\text { Temperature }\left({ }^{\circ} \mathrm{C}\right)^{\mathrm{a}} \\
\text { Relative humidity }\end{array}$ & Max. 32, Min. 24.2, Avg. 27.2 \\
$(\%)^{\mathrm{a}}$ & Max. 90, Min. 56, Avg. 77 \\
\end{tabular}

a Data obtained from a meteorological monitoring station lies between $3^{\circ} 06^{\prime} 25^{\prime \prime}$ and $101^{\circ} 30^{\prime} 12^{\prime \prime}$, and $60.8 \mathrm{~m}$ above sea level

\section{Experimental design}

To provide data to quantify total $\mathrm{CH}_{4}$ emissions from the three landfills, a square portion at each study area was overlaid with a grid of small squares to identify the measuring points. The grid square centers were marked with wooden sticks to specify sampling point locations (Mulla and McBratney 2002). Additional sampling locations were marked at shorter distances to provide an adequate number of samples to better develop a semi-variogram model and to define the flux spatial variability at small distances (Mulla and McBratney 2002). Grid characteristics and the total number of measuring points from each landfill are shown in Table 2. Surfer 8 software was used to estimate
Table 2 Characteristics of square grid sampling in each landfill

\begin{tabular}{llll}
\hline Grid characteristics & Air Hitam & Jeram & Sungai Sedu \\
\hline Area $\left(\mathrm{m}^{2}\right)$ & 1,764 & 3,600 & 992 \\
Dimensions $(\mathrm{m} \times \mathrm{m})$ & $7 \times 7$ & $10 \times 10$ & $3.5 \times 3.5$ \\
Number of samples & 73 & 81 & 80 \\
Minimum samples spacing $(\mathrm{m})$ & 3.5 & 5 & 3.5 \\
\hline
\end{tabular}

the average $\mathrm{CH}_{4}$ emissions using kriging and inverse distance weight (IDW) methods. The method that provided less cross-validation mean square residuals was used to estimate total emissions.

For $\mathrm{CH}_{4}$ emission measurements, a square flux chamber was fabricated (Fig. 2). The chamber volume was $80 \mathrm{~L}$, while the area was $0.4 \mathrm{~m}^{2}$ (Stern et al. 2007). The chamber area was chosen to meet the objectives of this study and was not so large that the environmental controls could not be assumed to be uniformly distributed over the enclosed surface area and not so small as to restrict the spatial variability of the emission rate. The chamber comprised a digital temperature module for measuring headspace gas temperature and a small propeller for attaining sufficient mixing of gases inside the chamber headspace (Cheng et al. 2010). Four sequential gas samples were extracted from the chamber headspace into a $50-\mathrm{mL}$ gas-tight syringe at predetermined intervals $(5 \mathrm{~min})$.

The wet and dry seasons in the landfills under the study were classified based on 19-year (1990-2008) monthly rainfall data obtained from the Department of Irrigation 


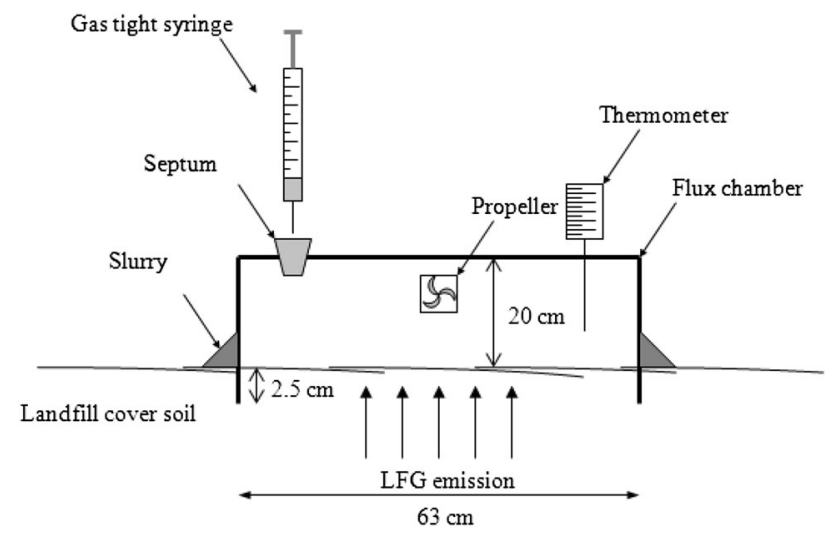

Fig. 2 Static flux chamber design and deployment in landfill cover soil

and Drainage, Ampang, Malaysia. The months provided highest rainfall relative frequency were considered as wet season, while those provided lowest rainfall relative frequency were considered as dry season. Emissions measurements during the wet season were undertaken from September to December 2010 at the three landfills, whereas dry season measurements were undertaken during February, March, May, and June from the Jeram and Sungai Sedu landfills only. Measuring $\mathrm{CH}_{4}$ emissions at the Air Hitam landfill during the dry season was not possible because a gas collection system was being constructed during the measurement period. All measurements were performed between 8 and 11 a.m. to minimize the diurnal effect. The total number of measuring points during the wet and dry season was identical at the two landfills that had readings taken during both wet and dry seasons. Atmospheric pressure and air temperature were also monitored.

Four monitoring locations at each landfill were chosen randomly to investigate the $\mathrm{CH}_{4}$ oxidation capacity. LFG $\left(\mathrm{CH}_{4}\right.$ and $\left.\mathrm{CO}_{2}\right)$ emissions on surface and soil gas concentration profiles at those locations were measured between 9 and 11 am twice a month from October 2010 to January 2011 at the Air Hitam landfill and from September 2010 to July 2011 at the Jeram and Sungai Sedu landfills. Soil gas was trapped by preinstalled stainless steel tubes in accordance with Kiese and Butterbach-Bahl (2002) and collected using $10-\mathrm{mL}$ gas-tight syringes for direct analysis. The concentrations of three main soil gases were investigated: $\mathrm{CH}_{4}, \mathrm{CO}_{2}$, and $\mathrm{O}_{2}$. The combination of surface LFG emissions and soil gas concentration profiles was used to estimate $\mathrm{CH}_{4}$ oxidation in the soil cover in accordance with Christophersen et al. (2001).

Gas concentration analysis and emission calculation

A Varian Micro-GC (CP-4900) equipped with an Molar sieves $5 \AA$ (MS5 $\mathrm{A}, 10 \mathrm{~m}$ ) and a PolarPlot Q (PPQ, $10 \mathrm{~m}$ )
Table 3 Micro-GC parameters for gas determination

\begin{tabular}{lll}
\hline Micro-GC parameters & \multicolumn{2}{l}{ Varian Micro-GC CP49000 } \\
\hline Column & MS5 $\AA, 10 \mathrm{~m}$ & $\mathrm{PPQ}, 10 \mathrm{~m}$ \\
Detector & $\mathrm{TCD}^{\mathrm{a}}$ & $\mathrm{TCD}$ \\
Oven temperature $\left({ }^{\circ} \mathrm{C}\right)$ & 80 & 40 \\
Column head pressure $(\mathrm{kPa})$ & 150 & 150 \\
Carrier and reference gas & $\mathrm{Helium}$ & $\mathrm{Helium}$ \\
Detection of & $\mathrm{O}_{2}$ & $\mathrm{CH}_{4}$ and $\mathrm{CO}_{2}$
\end{tabular}

a Thermal conductivity detector

column module was used for analysis of landfill and soil gas concentrations. Helium gas $(99.999 \%)$ was used as a carrier gas for the thermal conductivity detector at a flow rate 80 psi. Further details of the Micro-GC parameters are shown in Table 3.

Each gas sample was analyzed at least twice and the average was determined (Eklund 1992). The level of emissions, $F\left(\mathrm{~g} \mathrm{~m}^{-2} \mathrm{~d}^{-1}\right)$, was calculated as given in Eq. (1) (Abichou et al. 2006a):

$F=P V M U(\mathrm{~d} c / \mathrm{d} t) /(A T R)$

where $P$ is pressure $(1 \mathrm{~atm}), V$ is the chamber volume ( $80 \mathrm{~L}$ ), $M$ is the molar mass ( 16 and $44 \mathrm{~g} / \mathrm{mol}$ for $\mathrm{CH}_{4}$ and $\mathrm{CO}_{2}$, respectively), $U$ is the units conversion factor $\left(0.00144 \mathrm{~L} \min \mu \mathrm{L}^{-1} \mathrm{~d}^{-1}\right), A$ is the area covered by the chamber $\left(0.4 \mathrm{~m}^{2}\right), T$ is chamber temperature $(\mathrm{K})$, and $R$ is the gas constant $\left(0.08205 \mathrm{~L}^{\mathrm{atm} \mathrm{K}} \mathrm{K}^{-1} \mathrm{~mol}^{-1}\right)$. A nonzero flux was reported only when the regression coefficient $\left(R^{2}\right)$ for the linear regression of four sequential concentrations over time $(\mathrm{d} c / \mathrm{d} t)$ was larger than 0.85 (Zhang et al. 2008); otherwise, a zero flux was reported (Abichou et al. 2006b).

Method of calculation of $L_{\mathrm{o}}$ and $k$ values

To estimate the $L_{\mathrm{o}}$ and $k$ values, the total $\mathrm{CH}_{4}$ emissions from the field investigation and $\mathrm{CH}_{4}$ oxidation results were modeled using the IPCC 1996 FOD model (Eq. 2):

$\begin{aligned} Q= & {\left[0.717 \times 10^{-6} \times L_{\mathrm{o}} \times W \times\left(e^{-k c}-e^{-k t}\right)-R\right] } \\ & \times(1-\mathrm{OX})\end{aligned}$

where $Q$ is the total $\mathrm{CH}_{4}$ emission in the current year $(\mathrm{Gg})$, $0.717 \times 10^{-6}$ is a conversion factor, $W$ is the average annual waste acceptance rate $(\mathrm{t})$ during the active life of the landfill, $c$ is the time since the landfill was closed (y), $t$ is the time since the landfill was opened (y), $R$ is the $\mathrm{CH}_{4}$ recovered $(\mathrm{Gg})$, and $\mathrm{OX}$ is the oxidation factor (fraction). The OX value reflects the amount of $\mathrm{CH}_{4}$ oxidized in the soil.

The total $\mathrm{CH}_{4}$ emissions from each landfill site were estimated by multiplying the study area by the geospatial $\mathrm{CH}_{4}$ mean emissions. The total $\mathrm{CH}_{4}$ emissions value was 
input into the model in $\mathrm{Gg}$ year $^{-1}$. The value of $L_{\mathrm{o}}$ depends on waste composition and the fraction of organic carbon present, while the value of $k$ is controlled by a number of factors such as moisture content, nutrient availability, $\mathrm{pH}$, and temperature (IPCC 1996). However, waste moisture content is the main factor that affects the $k$ value (IPCC 1996). The estimation of the $L_{\mathrm{o}}$ value in this research was based on the assumption that the composition of municipal solid waste (MSW) in Malaysian regions was almost same and comprised similar amounts of DOC. Therefore, the value of $L_{\mathrm{o}}$ (in $\mathrm{m}^{3} \mathrm{t}^{-1}$ ) in Eq. (2) was assumed to be the same for both the Air Hitam and Jeram sanitary landfills. While both landfills supported fully anaerobic processes, the Sungai Sedu open dumping landfill was a semi-anaerobic environment, with aerobic processes at shallow depths due to air penetration and anaerobic processes in the deeper layers. This variation in the waste decomposition processes resulted in different $L_{\mathrm{O}}$ values for sanitary and open dumping landfills. Therefore, the $L_{\mathrm{o}}$ value for the Sungai Sedu open dumping landfill was assumed to be $50 \%$ of that for the Air Hitam and Jeram sanitary landfills (Abushammala et al. 2011; Chiemchaisri et al. 2007). Because waste moisture content is the main controlling factor affecting the value of $k\left(\right.$ year $\left.^{-1}\right)$ in Eq. (2), the $k$ value was estimated during the wet and dry seasons for each landfill.

The $W(t)$ in Eq. (2) was estimated using study site surface area $\left(A, \mathrm{~m}^{2}\right)$, depth of waste $\left(d_{\mathrm{w}}, \mathrm{m}\right)$, number of operation years $(n)$, and waste density in landfill $\left(\rho_{\mathrm{w}}\right.$, $\mathrm{t} \mathrm{m}^{-3}$ ) (Eq. 3). Williams (2005) reported that typical waste densities in landfills ranged from 0.60 to $0.85 \mathrm{t} \mathrm{m}^{-3}$ based on the amount of biodegradable and inert waste present. Landfill waste densities in this study were assumed to be in the range of $0.60-0.85 \mathrm{t} \mathrm{m}^{-3}$ based on site characteristics and taking into account that biodegradable waste accounted for up to $85 \%$ of total waste generation in Malaysia (Kathirvale et al. 2003). Waste settlement depth over years of landfills closure was considered through the estimation of the current waste depth. Williams (2005) reported that waste settlement in landfills ranges between 10 and $40 \%$ based on the amount of organic content of the waste. Thus, it was assumed that $10 \%$ waste settlement occurred at the Jeram landfill where the cell was recently closed and the waste depth was less than at the other landfills (Table 4). The waste settlement at Air Hitam was assumed to be $20 \%$ due to the longer time of closure and greater waste depth. Waste settlement at the Sungai Sedu open dumping landfill was assumed to be $15 \%$ due to the longer time required for waste stabilization compared with a sanitary landfill.

$W=\left(\frac{A \times d_{\mathrm{w}} \times \rho_{\mathrm{w}}}{n}\right)$

The values for $c$ and $t$ in Eq. (2) were based on the landfill study area information shown in Table 4. The
Table 4 Landfill study area information

\begin{tabular}{llll}
\hline Landfill & $\begin{array}{l}\text { Average waste } \\
\text { depth }(\mathrm{m})\end{array}$ & $\begin{array}{l}\text { Began } \\
\text { operation }\end{array}$ & $\begin{array}{l}\text { End of } \\
\text { operation }\end{array}$ \\
\hline Air Hitam & 23 & 2003 & 2006 \\
Jeram & 10 & 2007 & 2008 \\
Sungai Sedu & 40 & 1998 & 2006 \\
\hline
\end{tabular}

$R$ parameter was set at zero throughout the calculation, where the landfills did not have a gas collection system in place during field sampling. The mean fraction of $\mathrm{CH}_{4}$ oxidation $(\mathrm{OX})$ was estimated from each study landfill and used in the model.

\section{Results and discussion}

$\mathrm{CH}_{4}$ emission rate from field investigations

The summary and descriptive statistics for the $\mathrm{CH}_{4}$ flux measurements are listed in Table 5. The negative $\mathrm{CH}_{4}$ fluxes indicate that soil cover consumes atmospheric $\mathrm{CH}_{4}$ (Abichou et al. 2006a). The $\mathrm{CH}_{4}$ emissions results were shown to be within the ranges presented by other researchers. For example, Spokas et al. (2006) reported field measurements of $\mathrm{CH}_{4}$ emissions ranging from 0.0004 to more than $4,000 \mathrm{~g} \mathrm{~m}^{-2} \mathrm{~d}^{-1}$, and Abichou et al. (2006b) reported $\mathrm{CH}_{4}$ emissions between -13.6 and $1,754.8 \mathrm{~g} \mathrm{~m}^{-2} \mathrm{~d}^{-1}$.

The IDW method provided less cross-validation mean square residuals than the kriging method; therefore, the IDW method was used to estimate the average $\mathrm{CH}_{4}$ emissions. This was consistent with Spokas et al. (2003) results, who found that the IDW method provided better estimation of average $\mathrm{CH}_{4}$ emissions than kriging method. However, the results of the $\mathrm{CH}_{4}$ emission modeling using the variogram model and counter maps generated by the Surfer 8 software and the $\mathrm{CO}_{2}$ emission and soil gas profiles are not presented within this paper. The average and total $\mathrm{CH}_{4}$ emission rates from the three landfills for both wet and dry seasons are shown in Table 6 (Note that only wet season data are available for Air Hitam).

It can be seen that the $\mathrm{CH}_{4}$ emission rates during the wet season were higher than those during the dry season at the two landfills that had readings taken during both wet and dry seasons. The total $\mathrm{CH}_{4}$ emission rates during the wet season were approximately 1.6 times higher than those during the dry season for both Jeram and Sungai Sedu landfills. This was corroborated by other researchers who found that the wet season produces higher $\mathrm{CH}_{4}$ emissions than the dry season (Fourie and Morris 2004; Wang-Yao et al. 2006). The average $\mathrm{CH}_{4}$ emissions from the Air Hitam and Jeram sanitary landfills during the wet season were 1.4 and 12.5 times, respectively, higher than the 
Table 5 Summary of descriptive statistics of the $\mathrm{CH}_{4}$ emissions $\left(\mathrm{g} \mathrm{m}^{-2} \mathrm{~d}^{-1}\right)$ from the three landfills

\begin{tabular}{|c|c|c|c|c|c|}
\hline \multirow[t]{2}{*}{ Landfill } & \multirow{2}{*}{$\begin{array}{l}\text { Air } \\
\text { Hitam } \\
\text { Wet } \\
\text { season }\end{array}$} & \multicolumn{2}{|l|}{ Jeram } & \multicolumn{2}{|c|}{ Sungai Sedu } \\
\hline & & $\begin{array}{l}\text { Wet } \\
\text { season }\end{array}$ & $\begin{array}{l}\text { Dry } \\
\text { season }\end{array}$ & $\begin{array}{l}\text { Wet } \\
\text { season }\end{array}$ & $\begin{array}{l}\text { Dry } \\
\text { season }\end{array}$ \\
\hline $\begin{array}{c}\text { Number of } \\
\text { samples }\end{array}$ & 73 & 81 & 81 & 80 & 80 \\
\hline Min. & -1.83 & 0 & 0 & 0 & -1.48 \\
\hline Median & 14.63 & 119.94 & 89.01 & 3.62 & 1.749 \\
\hline Max. & 181.83 & $1,602.22$ & 924.66 & $2,011.72$ & $1,645.94$ \\
\hline $\begin{array}{l}\text { Arithmetic } \\
\text { mean }\end{array}$ & 30.58 & 267.28 & 181.92 & 153.95 & 88.50 \\
\hline SD & 38.36 & 329.49 & 204.26 & 407.51 & 288.33 \\
\hline
\end{tabular}

$S D$ standard deviation

Table $6 \mathrm{CH}_{4}$ emissions at the three landfills during wet and dry seasons

\begin{tabular}{lcclll}
\hline Landfill & $\begin{array}{l}\text { Average } \mathrm{CH}_{4} \text { emissions } \\
\left(\mathrm{g} \mathrm{m}^{-2} \mathrm{~d}^{-1}\right)^{\mathrm{a}}\end{array}$ & & \multicolumn{2}{l}{$\begin{array}{l}\text { Total emissions } \\
\left(\mathrm{Gg} \mathrm{year}^{-1}\right)\end{array}$} \\
\cline { 2 - 3 } \cline { 6 - 6 } \cline { 5 - 6 } & Wet season & Dry season & & Wet season & Dry season \\
\hline Air Hitam & 30.4 & - & 0.0196 & - \\
Jeram & 264.8 & 169.8 & & 0.3480 & 0.2231 \\
Sungai Sedu & 21.3 & 13.25 & & 0.0077 & 0.0048 \\
\hline
\end{tabular}

${ }^{\text {a }}$ Geospatial average estimated using the IDW method

average emissions from the Sungai Sedu open dumping landfill during the wet season, while Jeram's average emissions was 8.7 times higher than Air Hitam's average emissions during the wet season. The average $\mathrm{CH}_{4}$ emissions from the Jeram sanitary landfills during the dry season was 12.8 times higher than the average emissions from the Sungai Sedu open dumping landfill during the dry season. This difference was attributed to the newer waste buried at the Jeram landfill, which produced higher $\mathrm{CH}_{4}$ emissions, and to the fully anaerobic processes governing waste decomposition at the Jeram sanitary landfill in contrast with the Sungai Sedu open dumping landfill.

\section{$\mathrm{CH}_{4}$ oxidation capacity}

The $\mathrm{CH}_{4}$ oxidation capacity was investigated at the three landfills. The total number of oxidation measurements performed in the Air Hitam, Jeram, and Sungai Sedu landfills were 32, 72, and 78, respectively (Table 7). The average $\mathrm{CH}_{4}$ oxidation capacities were $27.45,16.33$, and $52.47 \%$ at the Air Hitam, Jeram, and Sungai Sedu landfills, respectively. These results were in agreement with those reported in the literature, where Abichou et al. (2006b) investigated $\mathrm{CH}_{4}$ oxidation from four different locations at a MSW landfill without a gas collection
Table 7 Summary of descriptive statistics of the $\mathrm{CH}_{4}$ oxidation (\%) from the three landfills

\begin{tabular}{lccc}
\hline Landfill & Air Hitam & Jeram & Sungai Sedu \\
\hline Number of samples & 32 & 72 & 78 \\
Min. & 0.99 & 0 & 0.81 \\
Max. & 89.32 & 92.9 & 97.87 \\
Arithmetic mean & 27.45 & 16.33 & 52.47 \\
SD & 21.7 & 20.46 & 30.60 \\
\hline
\end{tabular}

system, located in Leon County, FL, USA. The mean $\mathrm{CH}_{4}$ oxidation capacities at the four locations were 19.5, 26.6, 14.4, and $25.2 \%$. However, Christophersen et al. (2001) measured $\mathrm{CH}_{4}$ oxidation from the Skellingsted landfill in Denmark during summer and winter. They found that in summer $100 \%$ of the $\mathrm{CH}_{4}$ was oxidized, while the oxidation capacity in winter was $89 \%$.

Air Hitam's oxidation capacity was 1.7 times higher than the oxidation capacity at Jeram. The higher oxidation capacity at Air Hitam compared with Jeram might be attributed to soil texture, where the Air Hitam soil cover is classified as poorly graded sand with gravel, while the Jeram soil is mainly marine clay soil. This was confirmed by Boeckx et al. (1997), who reported that coarse-textured soil had significantly higher $\mathrm{CH}_{4}$ oxidation than fine-textured soils. However, the status of landfill operation might affect $\mathrm{CH}_{4}$ oxidation capacity. Borjesson et al. (2007) determined an oxidation capacity of $0-10 \%$ for active landfills and 10-20\% for closed landfills. Furthermore, Oonk (2010) reported $\mathrm{CH}_{4}$ oxidation between 10 and $30 \%$ for landfills in operation and 10-60\% for closed landfills. The oxidation capacity at the Sungai Sedu landfill was 1.9 times higher than that at Air Hitam and 3.2 times higher than that at Jeram. This might be attributed to the soil consisting of poorly graded sand dominated by dumped waste. In addition, old landfills and open dumping landfills tend to produce lower $\mathrm{CH}_{4}$ concentration and fluxes than new landfills, which enable microbial $\mathrm{CH}_{4}$ oxidation in soil cover to uptake a high percentage of $\mathrm{CH}_{4}$. This was confirmed by Boeckx et al. (1996), who reported that the $\mathrm{CH}_{4}$ concentration and fluxes are some of the most important factors that affect $\mathrm{CH}_{4}$ oxidation capacities within landfill cover soils.

\section{IPCC 1996 FOD model parameters}

To estimate the $L_{\mathrm{o}}$ and $k$ parameters of the IPCC 1996 FOD model and to generalize them for Malaysian landfills, the landfill study area information shown in Table 4, the total $\mathrm{CH}_{4}$ emissions during the wet and dry seasons for the three landfills presented in Table 6 , and the average $\mathrm{CH}_{4}$ oxidation capacities at each landfill (Table 7) were used in Eq. (2). The $L_{\mathrm{o}}$ and $k$ values are shown in Table 8. Using Air Hitam and Jeram landfill information and the field 
Table $8 k$ and $L_{\mathrm{o}}$ values at the three sites

\begin{tabular}{lcll}
\hline Landfill & $L_{\mathrm{o}}\left(\mathrm{t} \mathrm{m}{ }^{-3}\right)$ & $k$-wet $\left(\right.$ year $\left.^{-1}\right)$ & $k$-dry $\left(\right.$ year $\left.^{-1}\right)$ \\
\hline Air Hitam & 151.7 & 0.136 & - \\
Jeram & 151.7 & 0.136 & 0.072 \\
Sungai Sedu & 75.9 & 0.008 & 0.0049 \\
\hline
\end{tabular}

investigation results in the IPCC 1996 FOD model resulted in $L_{\mathrm{o}}$ having a value of $151.7 \mathrm{t} \mathrm{m}^{-3}$, and $k$ having a value of 0.136 year $^{-1}$ during the wet season. The $L_{\mathrm{o}}$ value of the Sungai Sedu open dumping landfill was assumed to be $50 \%$ of that found for both sanitary landfills, as open dumping landfills involve semi-anaerobic processes which tend to produce less $\mathrm{CH}_{4}$ in contrast with sanitary landfills, which are fully anaerobic systems.

The $k$ values of the Jeram sanitary landfill during the wet and dry seasons were approximately 17 and 15 times, respectively, higher than the $k$ values for the Sungai Sedu open dump. The higher $k$ value at the sanitary landfill indicates increasing $\mathrm{CH}_{4}$ generation over time and implies faster waste decomposition at sanitary landfills than at open dumping landfills. Wang-Yao et al. (2006) reported higher $k$ values of sanitary landfills than open dumping landfills during both wet and dry seasons. The $k$ values of both the Jeram sanitary landfill and the Sungai Sedu open dumping landfill during the wet season were higher than those during the dry season by approximately 1.9 and 1.7 times, respectively. This greater value was attributed to a higher amount of waste moisture content during the wet season, which accelerates waste decomposition to produce more $\mathrm{CH}_{4}$ and facilitates nutrient transportation through waste layers. However, Wang-Yao et al. (2006) found that the $k$ values were approximately 7.5-9.6 times higher in the wet season than in the dry season for sanitary landfills, and between 2.1 and 11.5 times higher for open dumping landfills. Table 9 provides a summary of the $L_{\mathrm{o}}$ and $k$ values found by other researchers.

The results documented by CDM-PDD (2004) in Table 9 were estimated for the Krubong sanitary landfill in Melaka, Malaysia. The $L_{\mathrm{o}}$ value in their results was estimated by incorporating field measurement data of waste temperature and total organic content into a model used in Europe to estimate $L_{\mathrm{o}}$ value. Our value of $L_{\mathrm{o}}$ for the Jeram and Air Hitam sanitary landfills was consistent with their result, which confirmed the validity of our hypothesis regarding the similarity of waste composition in the two landfills. However, their estimation of the $k$ value was closer to our value for sanitary landfills during the wet season, which supports the generalization of our observed value of $k$ for sanitary landfills in Malaysia during the wet season. As shown in Table 9, our results for $L_{\mathrm{o}}$ and $k$ values were close to the values reported by the other researchers and were within the minimum and maximum values. However, the variation might be attributed to different
Table 9 Summary of the $L_{\mathrm{o}}$ and $k$ values reported in the literature

\begin{tabular}{|c|c|c|c|}
\hline References & Notes & $\begin{array}{l}L_{\mathrm{o}} \\
\left(\mathrm{m}^{3} \mathrm{t}^{-1}\right)\end{array}$ & $k\left(\right.$ year $\left.^{-1}\right)$ \\
\hline $\begin{array}{l}\text { CDM-PDD } \\
(2004)\end{array}$ & Estimation in Malaysia & 153 & 0.12 \\
\hline \multirow{2}{*}{$\begin{array}{l}\text { Alexander et al. } \\
\text { (2005) }\end{array}$} & USEPA Default & 100 & 0.04 \\
\hline & Clean Air Act Default & 170 & 0.05 \\
\hline $\begin{array}{l}\text { Stege et al. } \\
\text { (2009) }\end{array}$ & $\begin{array}{l}\text { Values divided by } \\
\text { states }\end{array}$ & $69-214$ & $0.01-0.3$ \\
\hline $\begin{array}{l}\text { Wang-Yao et al. } \\
\text { (2006) }\end{array}$ & Estimation in Thailand & - & $0.0001-0.192$ \\
\hline \multirow[t]{2}{*}{ IPCC (2006) } & $\begin{array}{l}\text { Wet tropical default } \\
\text { (bulk waste) }\end{array}$ & - & 0.17 \\
\hline & $\begin{array}{l}\text { Dry tropical default } \\
\text { (bulk waste) }\end{array}$ & - & 0.065 \\
\hline
\end{tabular}

waste composition and climate; in Malaysia, the waste contain high portion of organic content, and the climate is tropical characterized by uniform temperature, high humidity, and plenty of rain. Currently, measurements of $\mathrm{CH}_{4}$ emission being collected from different sanitary and open dumping landfills to verify the proposed $L_{\mathrm{o}}$ and $k$ values provided in this study.

\section{Conclusion}

This study attempted to evaluate $L_{\mathrm{o}}$ and $k$ values for Malaysian landfills for both the wet and dry seasons to accurately estimate total $\mathrm{CH}_{4}$ emissions from Malaysian landfills. Therefore, measurements of $\mathrm{CH}_{4}$ emissions and oxidation were taken at two landfills (Jeram and Sungai Sedu) during the wet and dry seasons and another during the wet season (Air Hitam), and were used with the IPCC 1996 FOD model to attain the research objective. It was clear from the field work that $\mathrm{CH}_{4}$ emissions during the wet season were higher than those emissions during the dry season for both sanitary landfills and the open dumping landfill. Furthermore, the average $\mathrm{CH}_{4}$ emissions measured from both sanitary landfills were higher than the average emissions measured at the open dumping landfill.

The oxidation measurements at the three landfills showed different results. The oxidation capacity at the Sungai Sedu landfill was approximately 1.9 times higher than that at Air Hitam and 3.2 times higher than that at Jeram, while Air Hitam's oxidation capacity was 1.7 times higher than Jeram's. This variation of $\mathrm{CH}_{4}$ oxidation was attributed to the variations in soil texture, soil properties, and the age of the buried waste.

The $L_{\mathrm{o}}$ value found in this research for both sanitary landfills was $151.7 \mathrm{~m}^{3} \mathrm{t}^{-1}$, while the $L_{\mathrm{o}}$ value for the Sungai Sedu open dumping landfill was assumed to be $50 \%$ of that for sanitary landfills. The $k$ values of the Jeram sanitary 
landfill during the wet and dry seasons were approximately 17 and 15 times, respectively, higher than $k$ values for the Sungai Sedu open dump landfill. The higher $k$ value at sanitary landfills indicates increasing $\mathrm{CH}_{4}$ generation over time due to faster waste decomposition at sanitary landfills compared with open dumping landfills. The values of $L_{\mathrm{o}}$ and $k$ found in this research for both sanitary landfills were consistent with the results found in the Krubong sanitary landfill in Melaka state, Southern part of Malaysia, which indicated the validity of our hypothesis regarding the similarity of waste composition at the two sanitary landfills in the study, and assists in generalizing our observed values for sanitary landfills in Malaysia during the wet season.

Acknowledgments This work was financed by Universiti Kebangsaan Malaysia (UKM) under research grant UKM-GUP-ASPL08-06-208. The authors gratefully acknowledge the Alam Flora and Worldwide Companies site engineers for their assistance in conducting this work and Tuwati B. Tuwati for his assistance with field sampling.

\section{References}

Abichou T, Chanton J, Powelson D, Fleiger J, Escoriaza S, Lei Y, Stern $\mathrm{J}$ (2006a) Methane flux and oxidation at two types of intermediate landfill covers. Waste Manage (Oxford) 26(11):1305-1312

Abichou T, Powelson D, Chanton J, Escoriaza S (2006b) Characterization of methane oxidation at a solid waste landfill. J Environ Eng 132(2):220-229

Abushammala MFM, Basri NEA, Basri H, El-Shafie AH, Kadhum AAH (2011) Regional landfills methane emission inventory in Malaysia. Waste Manage Res 29(8):863-873

Alexander A, Burklin C, Singleton A (2005) Landfill gas emissions model (LandGEM) Version 3.02 user's guide. US Environmental Protection Agency. Office of Research and Development, Washington, DC

Boeckx P, Cleemput OV, Villaralvo I (1996) Methane emission from a landfill and the methane oxidizing capacity of its covering soil. Soil Biol Biochem 28(10-11):1397-1405

Boeckx P, Cleemput OV, Villaralvo I (1997) Methane oxidation in soils with different textures and land use. Nutr Cycl Agroecosyst 49(1-3):91-95

Borjesson G, Samuelsson J, Chanton J (2007) Methane oxidation in Swedish landfills quantified with the stable carbon isotope technique in combination with an optical method for emitted methane. Environ Sci Technol 41(19):6684-6690

CDM-PDD (Clean Development Mechanism Project Design Document) (2004) Krubong Melaka LFG collection and energy recovery CDM project version 02. United Nations Framework Convention on Climate Change (UNFCCC)

Cheng X, Luo Y, Xu Q, Lin G, Zhang Q, Chen J, Li B (2010) Seasonal variation in $\mathrm{CH}_{4}$ emission and its ${ }^{13} \mathrm{C}$-isotopic signature from Spartina alterniflora and Scirpus mariqueter soils in an estuarine wetland. Plant Soil 327(1-2):85-94

Chiemchaisri C, Juanga JP, Visvanathan C (2007) Municipal solid waste management in Thailand and disposal emission inventory. Environ Monit Assess 135(1-3):13-20

Christophersen M, Kjeldsen P, Holst H, Chanton J (2001) Lateral gas transport in soil adjacent to an old landfill: factors governing emissions and methane oxidation. Waste Manage Res 19(6):595-612
Eklund B (1992) Practical guidance for flux chamber measurements of fugitive volatile organic emission rates. Air Waste Manag Assoc 42(12):1583-1591

Fourie AB, Morris JWF (2004) Measured gas emissions from four landfills in South Africa and some implications for landfill design and methane recovery in semi-arid climates. Waste Manag Res 22(6):440-453

IPCC (1996) Revised 1996 IPCC guidelines for national greenhouse gas inventories. Reference Manual, Intergovernmental Panel on Climate Change, 3 [Internet]. Available from http://www.ipccnggip.iges.or.jp/public/gl/invs6e.html. Accessed 10 October 2009

IPCC (2006) 2006 IPCC guidelines for national greenhouse gas inventories. IPCC National Greenhouse Gas Inventories Programme, Eggleston S, Buendia L, Miwa K, Ngara T, Tanabe K (eds) IGES, Japan

Kathirvale S, Yunus MNM, Sopian K, Samsuddi AH (2003) Energy potential from municipal solid waste in Malaysia. Renew Energy 29(4):559-567

Kiese R, Butterbach-Bahl K (2002) $\mathrm{N}_{2} \mathrm{O}$ and $\mathrm{CO}_{2}$ emissions from three different tropic forest sites in the wet tropics of Queensland, Australia. Soil Biol Biochem 34(7):975-987

Kumar S, Gaikwad SA, Shekdar AV, Kshirsagar PS, Singh RN (2004) Estimation method for national methane emission from solid waste landfills. Atmos Environ 38(21):3481-3487

Ministry of Housing and Local Government (2004) National Solid Waste Management Department. Ministry of Housing and Local Government, Kuala Lumpur, Malaysia

Mulla DJ, McBratney AB (2002) Soil spatial variability. In: Warrick AW (ed) Soil physics companion. CRC Press, USA

Oonk H (2010) Literature review: methane from landfills, methods to quantify generation, oxidation and emission. Oonkay! Fabianusstraat 12, 7333 BD Apeldoorn, the Netherlands

Scharff H, Jacobs J (2006) Applying guidance for methane emission estimation for landfills. Waste Manag (Oxford) 26(4):417-429

Spokas K, Graffa C, Morcetb M, Aran C (2003) Implications of the spatial variability of landfill emission rates on geospatial analyses. Waste Manag (Oxford) 23(7):599-607

Spokas K, Bogner J, Chanton JP, Morcet M, Aran C, Graff C, Golvan YM-L, Hebe I (2006) Methane mass balance at three landfill sites: what is the efficiency of capture by gas collection systems? Waste Manag (Oxford) 26(5):516-525

Stege GA, Davila JL, SCS Engineers (2009) User's manual Mexico landfill gas model, version 2.0. US Environmental Protection Agency, Washington, DC

Stern JC, Chanton J, Abichou T, Powelson D, Yuan L, Escoriza S, Bogner J (2007) Use of biologically active cover to reduce landfill methane emissions and enhance methane oxidation. Waste Manag (Oxford) 27(9):1248-1258

USEPA (United States Environmental Protection Agency) (1998) User's manual: landfill gas emission model version 2.0. Office of Research and Development, USEPA, Washington, DC

USEPA (United States Environmental Protection Agency) (2005) Landfill gas emissions model (LandGEM) version 3.02 user's guide. Office of Research and Development, USEPA, Washington, DC

Wang-Yao K, Towprayoon S, Chiemchaisri C, Gheewala SH, Nopharatana A (2006) Seasonal variation of landfill methane emissions from seven solid waste disposal sites in central Thailand. In: The 2nd joint international conference on: sustainable energy and environment (SEE 2006). Bangkok, 21-23 November. Bangkok, Thailand

Williams PT (2005) Waste treatment and disposal, 2nd edn. Wiley, New York

Zhang H, He P, Shao L (2008) Methane emissions from MSW landfill with sandy soil covers under leachate recirculation and subsurface irrigation. Atmos Environ 42(22):5579-5588 